\title{
RICO and a Uniform Rule of Accrual
}

\author{
Mary S. Humes
}

Three times in the past five years, the Supreme Court has issued decisions interpreting the civil remedy provisions of the Racketeer Influenced and Corrupt Organizations Act (RICO). ${ }^{1}$ Yet none of these decisions answers a threshold question: When does a civil RICO cause of action accrue ${ }^{2}$ Indeed, the Court explicitly sidestepped the issue in a case in which it decided the related issue of the length of RICO's statute of limitations. ${ }^{3}$ But a provision limiting the period of time in which an action may be brought is of no help unless a court knows when a cause of action under RICO accrues, and therefore when the four year limitations rule begins to run. ${ }^{4}$

A brief description of the RICO statute illustrates the complexity of the accrual issue as it relates to the RICO cause of action. ${ }^{5}$ RICO prohibits four types of activity: ${ }^{6}(1)$ the investing of monies earned through racke-

1. 18 U.S.C. \$\& 1961-68 (1988). For decisions, see infra note 2.

2 For the purposes of this Note, "accrual" refers to the point at which a cause of action may be maintained. BLACK's LAw DictionaRY 19 (5th ed. 1987) (defining “accrue"). The statute of limitations for the relevant action begins to run when the cause of action accrues. Id. at 835 .

The recent Supreme Court decisions on RICO are: H.J., Inc. v. Northwestern Bell Tel. Co., 109 S. Ct. 2893 (1989) (interpreting statute's pattern requirement); Agency Holding Corp. v. Malley-Duff \& Assocs, 483 U.S. 143 (1987) (four year limitations provision from Clayton Act applies to RICO); Sedima, S.P.R.L. v. Imrex Co., 473 U.S. 479 (1985) (prior conviction for criminal violation of RICO not necessary to maintain civil RICO action).

3. Agenc Holding, 483 U.S. at 157. The Court supplied RICO with a four year limitations provision based on the Clayton Act, $i d$. at $150-54,156$, but stated that because the earliest date the cause of action could have accrued in Agency Holding was well within the four year limitations period adopted in the decision, there was no need to decide the appropriate time of accrual for a civil RICO clairn. Id. at 156-57.

4. The start of a limitations period and the accrual of a cause of action are terms used synonymously by most courts. Ste Zenith Radio Corp. v. Hazeltine Research, Inc., 401 U.S. 321, 338, reh'g demed, 401 U.S. 1015 (1971); Clay v. Union Carbide Corp., 828 F.2d 1103, 1105 (5th Cir. 1987); Federal Sav. \& Loan Ins. Corp. v. Haralson, 813 F.2d 370, 376 (11th Cir. 1987); Spannaus v. United States Dep't of Justice, 824 F.2d 52, 56 (D.C. Cir. 1987). But see Volk v. D.A. Davidson \& Co., 816 F.2d 1406, 1412 (9th Cir. 1987) (in case where fraud is alleged, claim accrues when plaintiff sulfers injury, but statute of limitations does not begin to run until claim is discovered). In this Note, the two terms will be used synonymously.

5. Although RICO was passed in 1970 , it was not until a decade later that use of the private civil damages remedy proliferated. Before 1980 there were only nine reported decisions involving civil RICO. After 1980 the number grew geometrically. See Task Force Report on Civil RICO, A.B.A. Sec. Corp. Banking and Business Law, Report of the ad Hoc Civil RiCo Task Force 55 (1984) [hereinafter Task Force Report] (in database of approximately 270 published and unpublished Federal civil RICO cases that existed in 1984, 5 were decided in 1980,19 in 1981,35 in 1982,89 in 1983 , and 116 in 1984).

6. 18 U.S.C. $\$ 1962(\mathrm{a})-(\mathrm{d})(1988)$. 
teering activities ${ }^{7}$ in an enterprise engaged in interstate commerce; (2) using proceeds from the collection of an unlawful debt to make a similar investment; (3) conducting an enterprise through a pattern of racketeering activity; and (4) conspiring to violate any of the above prohibitions.

As nearly all civil RICO complaints allege the third prohibition as their predicate act, ${ }^{8}$ the elements of a claim in most RICO cases consist of: ${ }^{8}$ (1) an injury ${ }^{10}$ (2) resulting from the conduct of an enterprise,,$^{11}$ (3) through a pattern (4) of racketeering activity. It is the interaction of the injury requirement with the pattern element of RICO, defined as requiring plaintiff to allege "at least two acts of racketeering activity . . . within ten years . . . after the commission of a prior act of racketeering activity,"12 that makes accrual under RICO so problematic.

On the face of the statute, it is unclear whether plaintiff's cause of action accrues upon injury resulting from one act of such pattern or whether the claim accrues after plaintiff can allege a pattern of racketeering activity. ${ }^{13}$ For example, suppose plaintiff is one of several victims harmed by defendant's scheme to defraud a group of investors. Under some courts' interpretations, the statute of limitations begins to run after plaintiff sustains an injury from one act, even though he may be unaware of other injuries sustained by other victims and consequently unable to allege a pattern. ${ }^{14}$ Alternatively, some courts effectively have deferred accrual until plaintiff is able to allege a pattern. ${ }^{15}$ Federal courts' practice of deferring accrual of a Federal cause of action until plaintiff knows, or in exercise of reasonable diligence should know, of the injury ${ }^{16}$ adds more variables to the problem. Finally, the relationship of the four-year statute of limitations to the requirement that the predicate acts occur within ten years of each other provides another layer of uncertainty.

The variation in rules of accrual, moreover, results in widely differing outcomes for plaintiffs. Under some courts' interpretations of RICO ac-

7. 18 U.S.C. $\$ 1961$ (1) (1988) (defining racketeering activities to include such offenses as bribery, arson, extortion, and threats to commit any of above, as well other activities already criminalized elsewhere in U.S. Code, such as securities fraud, mail and wire fraud, embezzlement, and obstructing Federal investigation).

8. See Task Force Report, supra note 5, at 55 (97\% of all civil RICO actions brought under 18 U.S.G. $\S 1962(c))$.

9. Sedima, S.P.R.L. v. Imrex Co., 473 U.S. 479, 496 (1985); Keystone Ins. Co. v. Houghton, 863 F.2d 1125, 1129 (3d Cir. 1988) (elements of civil RICO).

10. 18 U.S.C. $\$ 1964$ (c) (1988).

11. An enterprise includes "any individual, partnership, corporation, association, or other legal entity, and any union or group of individuals associated in fact although not a legal entity." 18 U.S.C. $\S 1961$ (4) (1988).

12. 18 U.S.C. $\S 1961(5)(1988)$.

13. RICO's civil remedy provision permits suit by persons "injured in their business or property." 18 U.S.C. $\S 1964$ (c) (1988). The civil remedy section is thus silent on how the pattern element required by $\S 1962(\mathrm{c})$ relates to $\S 1964(\mathrm{c})$.

14. See discussion of discovery rules and cases cited infra notes 65-87 and accompanying text.

15. See discussion of last predicate act rule infra notes 87-96 and accompanying text.

16. See infra notes $66-70$ and accompanying text. 
crual, a plaintiff who is injured in 1980, discovers the injury in 1984, but does not discover a second injury until 1990 would be unable to recover for the 1984 injury, even though he suffered two injuries occurring within ten years of each other, the base line requirement for a RICO claim. ${ }^{17}$ The 1984 discovery triggers the four year limitations rule, so plaintiff becomes time barred in 1988, before he can allege a pattern that includes the 1990 injury. Other courts would defer accrual of the cause of action until plaintiff can allege a pattern. Under this view, plaintiff who files his claim in 1990 could recover for the entirety of acts taking place during $1980-90 .^{18}$

Currently, four different rules defining when a RICO cause of action accrues exist among the lower courts. ${ }^{18}$ Despite the seeming abundance of choices, courts faced with this issue have, in fact, few principles to guide them in their decisions. Unlike limitations provisions, for which courts have developed a body of Federal common law ${ }^{20}$ to guide them through a

17. This hypothetical example makes several assumptions. First, it assumes that RICO provides the plaintiff's only colorable claim. Though time barred under RICO, plaintiff may still be able to recover for an individual injury under another cause of action, depending upon the limitations rules of that action. Second, the hypotheticals in this Note assume that two racketeering acts occurring within ten years of each other constitute a pattern. The Supreme Court has held that such a fact situation may, but need not, constitute a pattern. See H.J., Inc. v. Northwestern Bell Tel. Co., 109 S. Ct. 2893, 2895-96 (1989); Sedima, S.P.R.L. v. Imrex Co., 473 U.S. 479, 496 n.14 (1985).

For a case in which plaintiff is unable to recover under RICO for the first injury if it occurs more than four years before the second injury, see State Farm Mut. Auto. Ins. Co. v. Ammann, 828 F.2d 4 (9th Cir. 1987) (discovery of each injury triggers four year statute of limitations beyond which plaintiff may not recover for such injury, though such injury may be used to establish pattern).

18. County of Cook v. Berger, 648 F. Supp. 433 , 435 (N.D. Ill. 1986) ("[S]o long as any of the predicate acts occur within the limitations period, a defendant should have to answer for all of his related and cóntinual acts of harm.").

19. While as many as five distinct rules for RICO accrual have existed, the current battle seems to be between two types of rules. Compare Bankers Trust Co. v. Rhoades, 859 F.2d 1096 (2d Cir. 1988), cert. denied sub nom. Soifer v. Bankers Trust Co., 109 S. Ct. 1642 (1989) and State Farm Mut. Auto Ins. Co. v. Ammann, 828 F.2d 4 (9th Cir. 1987) (new cause of action accrues each time plaintiff discovers new injury in pattern) with Keystone Ins. Co. v. Houghton, 863 F.2d 1125 (3d Cir. 1988); Charter Oak Ins. Co. v. Domberg, No. 83-4522 (N.D. Ill. Aug. 3, 1987) (WESTLAW DCT database); Citicorp Sav. of Ill. v. Streit, No. 84-7471 (N.D. Ill. Apr. 6, 1987) (WESTLAW DCT database); Perta v. Comprehensive Accounting Corp., No. 84-5484 (N.D. Ill. Jan. 23, 1987) (WESTLAW DCT database); Newman v. Wanland, 651 F. Supp. 20 (N.D. Ill. 1986); County of Cook v. Berger, 648 F. Supp. 433 (N.D. Ill. 1986) (statute of limitation begins to run with occurrence of last act in pattern of violative acts required by RICO). For courts applying the discovery rule, see Pocahontas Supreme Coal Co. v. Bethlehem Steel Corp., 828 F.2d 211 (4th Gir. 1987), affg Compton v. Ide, 732 F.2d 1429 (9th Cir. 1984); La Porte Constr. Co. v. Bayshore Nat'l Bank, 805 F.2d 1254, 1256 (5th Cir. 1986); Bowling v. Founders Title Co., 773 F.2d 1175, 1178 (11th Cir. 1985), cert. denied sub nom. Zoldessy v. Founders Title Co., 475 U.S. 1109 (1986) (also affirming Compton); Alexander v. Perkin Elmer Corp., 729 F.2d 576 (8th Cir. 1984) (applying state rule of accrual stating that plaintiff time barred if has sufficient knowledge of injury five years before filing claim, even if discovers more acts later).

For two other distinct views, apparently not adopted by any other courts, see Keystone Ins. Co. v. Houghton, 692 F.Supp. 466, 470-473 (E.D. Pa. 1988), rev'd, 863 F.2d 1125 (3d Cir. 1988) (cause of action accrues to plaintiff when he discovers last act in pattern of violation), Armbrister v. Roland Int'l Corp., 667 F. Supp. 802 (M.D. Fla. 1987) (holding that statute of limitations begins to run with occurrence of first act of pattern). See also discussion of Ammbrister, infra notes 104-11. For classification of these rules, see infra note 64 and accompanying text.

20. It is generally accepted that Federal courts have competence to declare as a matter of common law, or judicial legislation, rules which may be necessary to fill in the interstices or otherwise give 
maze of issues, ${ }^{21}$ no similar body of law governs accrual. Though no less a matter of Federal law, ${ }^{22}$ accrual questions rarely present any dilemmas. In most cases, when a statute requires only a single injury, the general Federal rule of accrual, which postpones the commencement of the limitations period until plaintiff discovers the injury, proves adequate. With RICO, however, the use of the general Federal rule-known as the discovery rule-as the sole rule of accrual presents the difficulties described above. $^{23}$

Federal courts have yet to develop any consistent principles for determining a rule of accrual in the cases when the discovery rule is unsatisfactory. Part I of this Note, after setting forth the need for a uniform rule of accrual, will propose such guidelines based on Federal principles governing accrual and on general Federal common law principles. Part II of the Note will then evaluate the several rules in light of these guidelines.

\section{A Proposed Analysis for a Uniform Rule of Accrual}

\section{A. The Need for a Uniform Rule of Accrual}

An argument that the Supreme Court should resolve the question of when a RICO cause of action accrues presupposes the need for a uniform rule of accrual among the circuits. First, such an argument must distinguish between the need for a uniform set of principles for determining the question of RICO accrual and the need for a single rule to be applied in

effect to statutes enacted by Congress. Mishkin, The Variousness of "Federal Law": Competence and Discretion in the Choice of National and State Rules for Decision, 105 U. PA. L. REv. 797, 800 (1957) (discussing Erie R.R. v. Tompkins, 304 U.S. 64 (1938)). Filling in a statute of limitations left open by Congress in a Federal cause of action provides a good example of the existence of Federal common law. Under this definition, which relies on competence to declare whether Federal or state law should be applied rather than on which law is eventually applied, determining a missing limitations provision is a matter of Federal common law even when a local rule is eventually deemed to apply. Agency Holding Corp. v. Malley-Duff \& Assocs., 483 U.S. 143 (1987) and its history illustrate that a Federal court's decision to apply state law is itself a Federal rule of decision. Prior to the Agency Holding decision, courts had applied the most analogous limitations rule of the forum state. See Wilson v. Garcia, 471 U.S. 261, 268 (1985) (actions under 42 U.S.C. \$ 1983 (1982) should apply state limitations provisions for personal injury). Adopting a uniform Federal rule of limitations for RICO was thus a departure from previous practice. The Agency Holding court, however, found compelling reasons for departing from precedent. Citing the similarity of the provisions for private treble damages actions found in both the Clayton Act and in RICO, the general intent of RICO's drafters to pattern the statute after the Glayton Act, and the need for a uniform rule of accrual to prevent forum shopping, the Court concluded that the Clayton Act "provides a far closer analogy [to RICO] than any available state statute." Agency Holding, 483 U.S. at 156. See generally Comment, The Parameters of Federal Common Lau: The Case of Time Limitations of Federal Causes of Action, 136 U. PA. L. REv. 1447 (1987) (discussing Ageng Holding in the context of Federal jurisprudence on statutes of limitation).

21. See, e.g., Agency Holding, 483 U.S. at 156 (issues include whether to apply Federal or local rule and which of several competing local rules should apply).

22. Accrual is a matter of Federal common law in that Federal law is applied to determine when a Federal right of action accrues. See Deary v. Three Un-Named Police Officers, 746 F.2d 185, 197 n.16 (3d Cir. 1984). Even when a state statute of limitations applies, Federal law determines when the statute of limitations begins to run. Compton, 732 F.2d at 1433.

23. See supra text accompanying notes 17-18. 
every case. Whether or not the latter may be appropriate for such a diverse and multi-faceted action as RICO, a set of principles outlining an approach to accrual issues would provide a unitary standard for RICO accrual and guide the shaping of accrual rules for other Federal causes of action. ${ }^{24}$ Second, in its decision to establish a uniform statute of limitations for RICO, the Court expressed a desire for uniformity among the states, for an end to forum shopping, and for a reduction of litigation. ${ }^{25}$ These rationales also support the need for a uniform rule of accrual for RICO.

Finally, the need to reduce the vagueness of the RICO statute cannot be overstated. Courts repeatedly have attempted to solidify the statute's many ill-defined terms. For example, at the Supreme Court's direction, most lower courts in recent years have directed their attention to defining the term "pattern." ${ }^{\text {"2 }}$ The Court's recent interpretation of "pattern" indicates that it largely is to be considered case by case. ${ }^{27}$ Resolving uniformly when a RICO cause of action accrues would provide an alternate, if currently overlooked, means of resolving RICO disputes at the pre-trial stage without the need to divine the meaning of disputed terms.

Because the Court appears to be backing away from any judicial attempt to limit RICO's scope where Congress fails to do $\mathrm{so}^{28}$ any argument in favor of resolving the accrual of a RICO action that is justified on the basis of restricting claims at the outset should be viewed with caution. Yet the interpretation of any of RICO's terms necessarily results in restriction; a new definition will exclude some meanings. Moreover, a court's authority to interpret accrual, a matter omitted from the RICO statute, is greater than its authority to restrict terms explicitly set forth in the statute. Determining accrual for a Federal cause of action is a gapclosing function traditionally filled by courts; restriction of the statute through the choice of one rule of accrual over another poses less of a

24. Examples of other areas of law in which accrual remains uncertain include antitrust and conspiracy, as well as employment discrimination under Title VII. See, e.g, Held v. Gulf Oil Co., 684 F.2d 427 (6th Cir. 1982) (accrual of Title VII claim); Smith v. American Presidential Airlines, Ltd., 571 F.2d 102 (2d Cir. 1978) (same); Note, Complexities of Accrual: The Antitrust Statute of Limitalions in a Contractual Context, 31 UCLA L. Rev. 1061 (1984) (antitrust accrual rules); Annotation, Whitn Does Statute of Limitations Begin to Run Against Civil Action or Criminal Prosecution for Conspiracy? 62 A.L.R.2D 1369 (1958) (conspiracy accrual).

25. Agency Holding Corp. v. Malley Duff \& Assocs., 483 U.S. 143, 148, 154 (1987).

26. See H.J ., Inc. v. Northwestern Bell Tel. Co., 109 S. Ct. 2893 (1989); Sedima, S.P.R.L. v. Imrex Co., 473 U.S. 479 (1985). For a discussion of lower court cases interpreting RICO's pattern requirement prior to the Northu'estern Bell case, see Note, Clarifying a "Pattern" of Confusion: $A$ Multi-Factor Approach to Cinil RICO's Pattern Requirement, 86 МICH. L. Rev. 1745, 1754-60 (1988), Note, Interprting RICO's "Pattern of Racketering Activity" Requirement After Sedima: Siparate Schemes, Episodes or Related Acts?, 24 CAL. W.L. REv. 1, 8-25 (1988).

27. Northu'stern Bell, 109 S. Ct. at 2902.

28. Id. at 2900; sep also Sedima, 473 U.S. at 498; Keystone Ins. Co. v. Houghton, 863 F.2d 1125, 1128 (3d Cir. 1988); Comment, All the Myriad Ways: Accrual of Civil RICO Claims in the Wake of Agency Holding Corp. v. Malley-Duff, 48 LA. L. REv. 1411, 1421, 1425 \& n.56 (1988). 
threat of "judicial legislation" than does an effective rewriting of the statute's explicit terms. ${ }^{29}$

\section{B. Procedure for Deriving a Rule of Accrual}

A combination of statutory interpretation and Federal common law determines when a Federal cause of action accrues. ${ }^{30}$ Absent any discussion of accrual in the statute or legislative history, ${ }^{31}$ a court must turn to judicial interpretations of analogous issues.

Statutes of limitation present such an analogous issue. Both accrual and limitations provisions are matters of statutory interpretation. Rules of accrual are integral to limitations rules, as a limitation rule cannot be applied until the question of when the limitations period begins to run is determined..$^{32}$ Similarly, just as courts determining a missing statute of limitations must weigh plaintiff's rights against those of the defendant, ${ }^{33}$ so courts determining when a cause of action accrues must consider such a balance. The analysis developed in Agency Holding Corp. v. Malley Duff E Associates ${ }^{34}$ to determine RICO's statute of limitations therefore provides a model for determining an appropriate rule of accrual.

\section{The Agency Holding Procedure for Determining a Statute of Limitations}

The Agency Holding Court sets out a two-part analysis for determining a statute of limitations. The first step requires finding an analogous cause of action from either state or Federal law. ${ }^{35}$ This part of the procedure involves "characterizing the claim," that is, determining the overall nature of the claim (e.g., fraud, personal injury) to find the cause of action most

29. For examples of Federal courts imposing rules of accrual of varying degrees of strictness in the antitrust context, see Note, supra note 24, at 1066-74 (discussing cases).

30. Ross v. Johns-Manville, 766 F.2d 823, 826 (3d Cir. 1985) (accrual is matter of statutory construction of statute of limitations); see Deary v. Three Un-Named Police Officers, 746 F.2d 185, 197 n.16 (3d Cir. 1984) (accrual is matter of Federal common law). The line between Federal common law and statutory interpretation is blurred. Recent commentators have settled on a definition that recognizes the link between the two functions:

The difference between "common law" and "statutory interpretation" is a difference in emphasis rather than a difference in kind. The more definite and explicit the prevailing legislative policy, the more likely a court will describe its lawmaking as statutory interpretation; the less precise and less explicit the perceived legislative policy, the more likely a court will speak of common law.

Westen \& Lehman, Is There Life for Erie After the Death of Diversity? 78 MiCH. L. Rev. 311, 332 (1980); see also P. Bator, D. Meltzer, P. Mishkin \& D. Shapiro, Hart \& Wechsler's The Federal Courts and THE Federal SySTEM 863 (3d ed. 1988) ("Statutory interpretation shades into judicial lawmaking on a spectrum, as specific evidence of legislative purpose with respect to the issue at hand attenuates."').

31. See Ex Parte Collett, 337 U.S. 55, 61 (1949) ("[T]here is no need to refer to the legislative history where the statutory language is clear.").

32. See cases cited supra note 4.

33. See cases cited infra note 50 .

34. 483 U.S. 143 (1987).

35. Id. at 156. 
analogous to it. ${ }^{36}$ The second step considers whether the Federal policies at stake or the practicalities of the litigation require altering the rule based on the initial characterization. ${ }^{37}$

\section{Characterizing the Claim for Purposes of Accrual}

A court faced with determining an appropriate rule of accrual would first "characterize" the claim. ${ }^{38}$ The first step in the analysis should consider whether the RICO claim is characterized best as (1) an action to recover for a continuing violation, ${ }^{38}$ or (2) an action to recover for harms caused by particular predicate acts, many of which are kept secret from the plaintiff at the time of injury. ${ }^{40}$ If RICO is primarily an action to recover for a continuing violation, then the claim should not accrue until the plaintiff can allege a pattern. But if compensating injury was the main concern of the RICO drafters, then the claim should accrue upon injury or when plaintiff becomes aware of such injury.

Neither characterization is entirely satisfactory. The pattern requirement suggests the RICO action is similar to a continuing violation, but the nature of the predicate acts suggests that RICO is similar to an action to recover for fraud. The Agency Holding decision provides support for this dual nature of RICO. The Court held that the predicate acts that establish racketeering activity under RICO are "far-ranging, and cannot be reduced to a single generic characterization." 41

The fact that no single characterization applies calls for an accrual rule that takes account of the several possible characterizations of RICO. Yet of the several characterizations, that of RICO as a continuing violation

36. Id; see Wilson v. Garcia, 471 U.S. 261, 268 (1985) ("The characterization of $\$ 1983$ for statute of limitations purposes is derived from the elements of the cause of action, and Congress' purpose in providing it."); see also UAW v. Hoosier Cardinal Corp., 383 U.S. 696, 706 (1966) (determining limitations period for claims arising under $\$ 301$ of the Labor Management Relations Act by "characterization").

37. Agency Holding, 483 U.S. at 147-48 (Federal policies might justify deviation from presumption that state limitations period applies).

38. The Agengy Holding court's consideration of various characterizations of the RICO claim for the purpose of determining the statute of limitations provides some guidance for characterizing the claim for accrual purposes. In the statute of limitations context, debate revolved around whether the appropriate period should be identified by directly analogizing the predicate offenses to the causes of action listed in states' general statutes of limitations or by characterizing the entire RICO cause of action as a matter of Federal law and then ascertaining an analogous statutory period. Comment, supra note 20 , at 1481 .

39. E.g., County of Cook v. Berger, 648 F. Supp. 433, 434 (N.D. Ill. 1986); see infra notes $91-95$ and accompanying text.

40. This is the characterization implicitly assumed by those courts applying the discovery rule.

Although RICO does specifically outlaw conspiracies to violate the substantive provisions of the statute. . . RICO's civil remedy section permits suit by persons injured in their businesses or property. . . . The civil remedy provision's focus upon injury as opposed to existence of a conspiracy suggests that the normal federal rule on accrual should apply . . . . Compton v. Ide, 732 F.2d 1429, 1433 (9th Cir. 1984).

41. Agenc Holding, 483 U.S. at 143, 152; see also Malley-Duff \& Assoc. v. Crown Life Ins. Co., 792 F.2d 341, 348 (3d Cir. 1986) (RICO concepts such as "enterprise," "pattern," and "racketeering activity" "simply unknown" to common law). 
stands out. The Court in Agency Holding held that the Clayton Act provides the closest analogy to RICO. ${ }^{42}$ Actions under the Clayton or Sherman Acts do not require a pattern, but antitrust law has recognized the ongoing nature of antitrust violations. While an antitrust action normally accrues when defendant commits an act that injures plaintiff's business, ${ }^{43}$ courts have carved out an exception to this accrual rule in the case of a continuing violation. ${ }^{4}$ In such a case, each violative act triggers a new limitations period. ${ }^{45}$ The plaintiff may recover only for those acts that occurred in the four years immediately preceding the filing of the claim. ${ }^{46}$

RICO too can be characterized as an action to recover for a continuing violation. Congress enacted RICO to prevent the infiltration of legitimate businesses by organized crime. ${ }^{47}$ The desire to remedy the gradual process of such infiltration suggests a legislative intent to create a remedy for an ongoing harm analogous to a continuing violation. ${ }^{48}$

\section{Federal Policies to be Weighed in a Rule of Accrual}

In addition to characterization, the analysis also should consider any Federal policies or practicalities of litigation that may, when weighed against the characterization, alter the calculus. One such Federal policy is the near universal application of the discovery rule of accrual to any Federal cause of action. ${ }^{49}$ Another consideration is the achievement of a balance between plaintiffs' and defendants' rights, a policy derived from the statute of limitations context. ${ }^{\text {so }}$

Because the discovery rule does not apply to antitrust law, ${ }^{51}$ a strict

42. Agency Holding, 483 U.S. at 150.

43. Zenith Radio Corp. v. Hazeltine Research, Inc., 401 U.S. 321, 338, reh'g dented, 401 U.S. 1015 (1971).

44. Hanover Shoe, Inc. v. United Shoe Mach., 392 U.S. 481, 495 (1968) (approving damages award based on continuing violation); Hennegan v. Pacifico Creative Serv., 787 F.2d 1299, 1300 (9th Cir.), cert. dentied, 479 U.S. 886 (1986) (continuing violation occurs when plaintiff's interests repeatedly invaded; cause of action arises each time plaintiff injured); see infra note 88. See generally 54 C.J.S. Limitations of Actions $§ 203$ (1987) (continuing violation rule applies when plaintiff alleges continuing conspiracy to violate antitrust laws or, in absence of conspiracy, when defendant commits act which by its nature is continuing antitrust violation).

45. Zenith Radio, 401 U.S. at 338.

46. Id.

47. Bradley, Racketeers, Congress and the Courts: An Analysis of RICO, 65 IowA L. REv. 837, $840-45,892$ (1980).

48. See, e.g., County of Cook v. Berger, 648 F. Supp. 433, 435 (N.D. Ill. 1986).

49. Sep infra note 65 and accompanying text.

50. Agency Holding, 483 U.S. at 156 (statute of limitations must reflect "congressional balancing of the competing equities unique to civil RICO actions"); Wilson v. Garcia, 471 U.S. 261, 275 (1985) (balancing uniformity, certainty, minimization of unnecessary litigation); see also United States v. Kubrick, 444 U.S. 111, 117 (1979) (statute of limitations represents judgment that it is unjust not to put adversary on notice to defend within specified length of time and that right to be free of stale claims comes to prevail over right to prosecute them) (citation omitted). The same considerations seem to apply to determining a rule of accrual as a necessary procedure for the application of the statute of limitations. See 54 C.J.S., supra note $44, \S 81$.

51. Zenith Radio Corp. v. Hazeltine Research, Inc., 401 U.S. 321, 338, reh'g denied, 401 U.S. 1015 (1971); Pace Indus. v. Three Phoenix Co., 813 F.2d 234, 237 (9th Cir. 1987); see also 54 
adoption of the continuing violation rule of accrual based on antitrust law would not include any time for the plaintiff to discover his or her harm. Rather, the statute of limitations begins to run with the occurrence of each violative act, regardless of when plaintiff discovers it. ${ }^{\mathbf{2 2}}$ Yet, in the case of RICO, the rationales behind the development of the discovery rule as the general Federal rule may compel the application of discovery principles.

The discovery rule first was applied as the general Federal rule of accrual in cases involving fraud. ${ }^{53}$ Notions of equity incorporated in the Federal rules may account for the later expansion of the rule to non-fraud Federal actions. ${ }^{54}$ Beyond general notions of equity, the discovery rule's origins in fraud cases argue for the application of discovery principles to a RICO action. Unlike the Clayton Act, which targets harms to competition induced by force rather than by fraud, racketeering injuries by definition include harms from fraud (securities, wire or mail fraud) and harms resulting from force (e.g., extortion). ${ }^{\mathrm{s}}$ Therefore, Federal judicial practice as well as legislative policies demand that courts make some allowance for the plaintiff alleging fraud. By running the statute of limitations from the discovery of the harm, rather than from the occurrence of each violative act, the accrual rule will account adequately for those respects in which RICO is not analogous to the Clayton Act.

Just as the plaintiff has the right to a reasonable time in which to bring his claim, so a defendant enjoys the right eventually to be free of stale claims. ${ }^{56}$ Courts must take defendant's right into account as another Federal policy to consider in deriving a rule of accrual. While a rule of accrual that allows recovery for all acts in an alleged pattern of racketeering-including those outside the limitations period-would not be unprecedented, ${ }^{57}$ such a rule would appear to encroach on defendant's right eventually to be free of old claims.

RICO's characterization as a continuing violation, however, suggests that the injury resulting from the pattern of acts is indivisible and there-

C. J.S., supra note 44, $\$ 203$ (cause of action under Clayton and Sherman Acts accrues with commission of act but statute of limitations in conspiracy to violate antitrust laws accrues with each separate injurious act). But of. infra notes 60-63 and accompanying text (discussing use of equitable tolling doctrine of fraudulent concealment in antitrust law).

52. Sir cases cited supra note 51.

53. Sie Bailey v. Glover, 88 U.S. (21 Wall) 342, 348 (1874).

54. Six Holmberg v. Armbrecht, 327 U.S. 392, 397 (1945); Moviecolor Ltd. v. Eastman Kodak Co. 288 F.2d 80, 83 (2d Cir.), cert. denied, 368 U.S. 821 (1961).

55. 18 U.S.C. $\$ 1961$ (1) (1988) (defining racketeering activities to include embezzlement as well as securities, mail and wire fraud). Inherent in injury based on fraud is an inability to discover the injury. BLACK's LAw Dictionary 594 (5th ed. 1979). An accrual rule for RICO should therefore allow plaintiff time to discover his injury.

56. United States v. Kubrick, 444 U.S. 111, 117 (1979).

57. Sie, e.g., Berkey Photo, Inc. v. Eastman Kodak Co., 603 F.2d 263, 295 (2d Cir. 1979), cert. dt nied, 444 U.S. 1093 (1980) (under Sherman Act, it is not necessary for act itself to have been committed within limitations period if extent of damages is speculative; no unfairness in depriving monopoly of fruits of unlawful conduct even though monopoly originated outside limitations period). 
fore that recovery of all damages is not an undue encroachment on defendant's rights. ${ }^{68}$ Moreover, the intersection of the definition of a pattern with the elements of a RICO cause of action places an outside limit on what plaintiff can recover outside the four year limitations period. To constitute a pattern under the statutory definition, acts must have occurred within ten years of each other. ${ }^{58}$ Thus, even if he can recover for injuries that took place more than four years ago, plaintiff will not be able to recover for any acts that took place more than ten years before the most recent alleged act.

\section{The Precedent for a Hybrid Rule: The Equitable Rule of Fraudu- lent Concealment}

The preceding section has shown that principles used to determine RICO's statute of limitations all indicate that an accrual rule for RICO should (1) recognize RICO's nature as an ongoing harm; (2) allow plaintiff time to discover his injury before his RICO claim accrues; and (3) while keeping in mind the balance between plaintiff's and defendant's rights, allow plaintiff an opportunity to recover for some acts outside the four year limitations period given that the injury is indivisible.

No monolithic rule can satisfy these requirements; RICO requires a hybrid rule of accrual which combines continuing violation principles with the discovery rule. The question then becomes whether past courts have altered traditional accrual doctrines to arrive at a hybrid rule. The doctrine of fraudulent concealment, applied to toll the accrual of a cause of action in antitrust law when the plaintiff can show the acts complained of were concealed from him fraudulently, provides a compelling precedent. ${ }^{60}$

Though presented as a tolling doctrine rather than as a rule of accrual, the doctrine of fraudulent concealment ${ }^{\mathbf{8 1}}$ has the same effect on a cause of

58. In recovering for acts outside the limitations period, plaintiff is actually recovering for a continuous series of acts, a portion of which became manifest within the preceding four years. $S_{t e}$ Comment, supra note 28 , at 1416 n.26. In addition, in situations where there is a lag time between the commission of the act and the realization of the injury, it may be hard to apportion an injury to a particular act or to estimate the amount of liability on the date of discovery.

59. See supra text accompanying note 12 .

60. Conmar Corp. v. Mitsui \& Co., 858 F.2d 499 (9th Gir. 1988), cert. denied sub nom. USL Corp. v. Conmar Corp., 109 S. Ct. 795 (1989); Moviecolor Ltd. v. Eastman Kodak Co., 288 F.2d 80 (2d Cir.), cert. denied, 368 U.S. 821 (1961). Unlike predicate acts under RICO, predicate acts under the Clayton and Sherman Acts are not inherently fraudulent (that is, they do not involve misrepresentation or omission, which would allow invocation of the discovery rule of accrual). But the predicate acts required to state a claim under the antitrust laws-conspiracy to engage in the restraint of trade, tying arrangements, and price discrimination-see 15 U.S.C. \$\$ 1, 13(a), 13(d) \& 13(e) (1982), contemplate agreements that are made in secret. Consequently, it is difficult for an antitrust plaintiff to find evidence of a predicate act at the time act occurs.

61. A finding that the statute of limitations has tolled requires a showing of facts which remove its bar of the action. 54 C.J.S., supra note $44, \$ 85$. The difference between the doctrine of fraudulent concealment and the discovery rule is the higher threshold that must be reached by the antitrust plaintiff to invoke the tolling doctrine. The plaintiff must show an affirmative act on the part of the defendant to conceal the harm from the plaintiff. Moviecolor, 288 F.2d at 88 . 
action as the application of the discovery rule: both delay the running of the limitations period. In antitrust law, if the plaintiff suffers a series of harmful acts that constitutes a continuing violation, the occurrence of each act triggers the accrual of a new cause of action. ${ }^{62}$ But if the plaintiff could show that an occurrence of an injurious act was fraudulently concealed from him, the start of the limitations period triggered by that act would be tolled during the period of concealment, until the plaintiff discovered or had reason to discover the harm. ${ }^{63}$

In short, RICO's accrual rule should be a hybrid rule; Federal courts need not adhere to a single rule, but may develop a rule that combines elements of various existing rules of accrual. Part II explains how courts either seem unaware of the hybrid rule option or, if courts do advocate a hybrid rule, fail to put forth a compelling rationale or cite a precedent for such a rule.

\section{The Current Rules for Accrual: Principles and Practice}

There are currently as many as five rules for the accrual of a RICO cause of action, depending on the degree of precision (or lack thereof) used by courts in distinguishing among the various rules: ${ }^{64}$ the discovery rule, the separate accrual discovery rule, the last predicate act rule, the last predicate act discovery rule, and the Clayton Act rule. This Part sets forth the several rules and determines which comports most closely with the analysis of Part I.

\section{A. Summary of Accrual Rules Currently Applied to RICO}

The five rules for accrual currently in existence may be divided into two broad groups. One group relies on the general Federal equitable principle of allowing the plaintiff time to discover his injury before the limitations period begins to run, and the other group derives from a Federal principle of accrual in the case of a continuing violation. While some rules rely on both principles to some extent, each rule treats one of the two as its primary concern.

\section{The Discovery Rule}

The discovery rule is the general Federal rule of accrual-the method which governs Federal causes of action in the absence of a specific desig-

62. See supra note 44 .

63. Moriecolor, 288 F.2d at $80,84,86$.

64. A commentator has grouped the rules into categories different from the ones employed in this Note: the discovery rule, the last predicate act rule, the last injury discovery standard, and the Clayton Act rule. Comment, supra note $28,1413-21$. The last injury discovery standard has been overruled since the publication of the Comment. Keystone Ins. Co. v. Houghton, 692 F. Supp. 466 (E.D. Pa. 1988), rev'd, 863 F.2d 1125 (3d Cir. 1988). This Note substitutes the last predicate act discovery rule for the last injury discovery rule. 
nation by Congress of another method. ${ }^{65}$ Under the discovery rule, a claim accrues when the plaintiff knows, or in the exercise of reasonable diligence should know, of the injury which is the basis for his action. ${ }^{66}$

Courts applying the discovery rule to RICO hold that plaintiff's cause of action accrues with the discovery of the first injury. ${ }^{67}$ This method may clash with the pattern requirement. If the claim accrues after the first injury but before the plaintiff can state a pattern, plaintiff may be time barred before he can state a claim. ${ }^{88}$ To avoid this problem, plaintiffs in these cases claimed to have suffered a single injury as the result of a scheme of mail, wire, or securities fraud. ${ }^{69}$

Despite these difficulties, many circuits have applied the discovery rule to RICO. ${ }^{70}$ The rationales invoked in support of the discovery rule are (1) that the discovery rule, as the general Federal rule of accrual, has the most authority and is therefore the easiest to adopt in the absence of a better rule; ${ }^{71}$ and (2) that the discovery rule works well when the RICO action is brought in conjunction with another Federal cause of action that will most likely use the discovery rule of accrual. ${ }^{72}$ These rationales are not compelling, especially if in some cases the discovery rule bars a plaintiff before he can even state a claim. ${ }^{73}$ Because of this defect, the discovery rule cannot be reconciled completely with the pattern requirement of RICO and is therefore not the best accrual rule for RICO actions.

65. Sep, e.g., United States v. Kubrick, 444 U.S. 111, 115 (1979) (Federal Tort Claims Act); Mullinax v. McElhenney, 817 F.2d 711, 717 (11th Cir. 1987) (42 U.S.C. $\$ 1983$ claim accrues when plaintiff knows or has reason to know of both injury and identity of perpetrator); Corwin v. Marney, Orton Investments, 788 F.2d 1063, 1068 (5th Cir. 1986), cert. denied sub nom. van Caspel v. Corwin, 109 S. Ct. 305 (1988) (securities fraud actions arising under $\$ 10(b)$ of Securities Exchange Act of 1934, 15 U.S.C. $§ 78 j(b)(1982)$ ); Tate v. Eli Lilly \& Co., 522 F. Supp. 1048, 1049 (M.D. Tenn. 1981) (personal injury). But of. Gurran v. Time Ins. Co., 644 F. Supp. 967, 972 (D. Del. 1986) (citing DEL. CoDE ANN. tit. 10, $\$ \S 8106,8119$ (1974 \& Supp. 1984)) (with exception of asbestos cases, cause of action accrues at first date action could be brought, and ignorance of injury does not delay running of statute). See generally text accompanying notes 53-54.

66. La Porte Constr. Co. v. Bayshore Nat'l Bank, 805 F.2d 1254, 1256 (5th Cir. 1986),

67. E.g., Gutfreund v. Christoph, 658 F. Supp. 1378 (N.D. Ill. 1987) (claim partially barred by statute of limitations when plaintiff suffers multiple injuries).

68. See supra text accompanying notes 17-18.

69. See Comment, supra note 28 , at 1414 (distinguishing single injury RICO claims, for accrual purposes, from claims alleging multiple injuries).

70. Riddell v. Riddell Wash. Corp., 866 F.2d 1480, 1489-90 (D.C. Cir. 1989); Pocahontas Supreme Coal Co. v. Bethlehem Steel Corp., 828 F.2d 211, 220 (4th Cir. 1987), affg Compton v. Ide, 732 F.2d 1429, 1433 (9th Cir. 1984); La Porte Conser. Co. v. Bayshore Nat'l Bank, 805 F.2d 1254, 1256 (5th Cir. 1986); Bowling v. Founders Title Co., 773 F.2d 1175, 1178 (11th Cir. 1985), cert. denied sub nom. Zoldessy v. Founders Title Co., 475 U.S. 1109 (1986) (affirming Compton, 732 F.2d at 1433); Alexander v. Perkin Elmer Corp., 729 F.2d 576, 577-78 (8th Cir. 1984) (applying state rule of accrual and stating that plaintiff time barred if he has sufficient knowledge of injury five years before filing claim, even if he discovers more acts later); Compton v. Ide, 732 F.2d 1429, 1433 (9th Cir. 1984).

71. See Compton, 732 F.2d at 1433.

72. Cf. Bowling, 773 F.2d at 1178.

73. See supra text accompanying notes 17-18. 


\section{The Separate Accrual Discovery Rule}

Some courts faced with the problem of fashioning an accrual rule when plaintiffs allege multiple injuries have attempted to solve the conflict between the discovery rule and the pattern requirement by adopting a variation of the discovery rule that also treats the action as a continuing violation. This rule is known as the separate accrual discovery rule. ${ }^{74}$ Under this variation, a new claim accrues-and a new four year limitations period begins to run-each time the plaintiff becomes aware of a new injury. ${ }^{75}$ In this way, the separate accrual discovery rule overcomes the flaw in the discovery rule that a plaintiff, unable to discover the second injury required to form a pattern under RICO, becomes time barred because the statute of limitations began to run with the discovery of the first injury.

Yet the reasoning that the two courts bring to bear in support of the benefits of the rule is insufficient. The opinion in State Farm Mutual Insurance Co. $v$. Ammann ${ }^{76}$ by failing to distinguish its rule from the Ninth Circuit case adopting the discovery rule, Compton v. Ide, ${ }^{77}$ never makes clear that the separate accrual discovery rule overcomes the difficulty of the discovery rule. The concurrence in Ammann, though it cites an antitrust continuing violation case as precedent for the rule adopted, does not offer any rationale for the continuing violation analogy. The concurrence does not even point out that the rule adopted by the Ammann court must deviate from a strict application of the continuing violation rule and allow plaintiff time to discover his injury if it is to follow Compton. ${ }^{78}$

74. Bankers Trust Co. v. Rhoades, 859 F.2d 1096 (2d Cir. 1988), cert. denied sub nom. Soifer v. Bankers Trust Co., 109 S. Ct. 1642 (1989); State Farm Mut. Auto Ins. Co. v. Ammann, 828 F.2d 4, 5 (9th Cir. 1987) (Kennedy, J. concurring) (new cause of action accrues each time plaintiff discovers new injury in pattern).

The Ammann court derives this new rule from analogizing a RICO action to an action to recover for a continuing violation in antitrust law. Under the continuing violation rule in accrual of antitrust law, each separate act committed by defendant triggers a new four year limitations period. See supra notes 45-46 and accompanying text. The Ammann rule differs from the antitrust rule in that each new discovery of an injury, as opposed to the mere occurrence of the injurious act, triggers a new limitations period.

75. Ammann, 828 F,2d at 5 (Kennedy, J. concurring). To meet the pattern requirement, plaintiff may allege acts occurring outside the limitations period, as long as such acts are within the ten year statutory definition of pattern. Though he may allege acts outside the four year limitations period, plaintiff may only recover for acts occurring inside the four year limitations period. Thus, a plaintiff discovering injuries in 1980 and 1984 is not time barred as long as he files his claim before 1988. Several subsequent opinions in other circuits have, however, failed to realize that the rule adopted in Ammann is distinct from the discovery rule. See, e.g., Riddell v. Riddell Wash. Corp., 866 F.2d 1480, 1489-90 (D.C. Cir. 1989) (stating that Bankers Trust court adopts discovery rule and citing earlier Compton opinion adopting discovery rule, instead of Ammann opinion, for proposition that Ninth Circuit applies discovery rule).

76. 828 F.2d 4 (9th Cir. 1987).

77. 732 F.2d 1429 (9th Cir. 1984).

78. Ammann, 828 F.2d at 5 ("the basis for our holding comes not from [Agency Holding] or Compton, but from Hennegan r. Pacifico Creative Serv., Inc. and Gibson v. United States") (citations omitted). Hennegan was an antitrust case. 787 F.2d 1299 (9th Cir.), cert. denied, 479 U.S. 886 (1986). Gibson was an action brought under 42 U.S.C. § 1983. 781 F.2d 1334 (9th Cir. 1986), cert. 
Nor does the analysis offered in Bankers Trust ${ }^{7}$ - the Second Circuit opinion adopting the separate accrual discovery rule-explain its decision to retain the principles of the discovery rule and also apply accrual principles from the context of a continuing violation. The court simply focuses on the need to apply the discovery rule, pointing out that RICO is only meant to compensate "persons injured in their business or property." The court uses the injury requirement of RICO to argue that the discovery rule of accrual must be a component of the new rule of accrual: Until plaintiffs find out about their injury, they will not have a right to sue. The opinion reasons that without a right to sue, "a civil RICO action cannot be held to have accrued." 81

This argument proves too much. The Bankers Trust court is in fact arguing that a statute's jurisdictional requirement of injury demands that the discovery rule of accrual apply to every action. The Clayton Act has a similar jurisdictional requirement, limiting the civil treble damages remedy to those persons "injured in [their] business or property." ${ }^{82}$ But as we have seen, plaintiffs bringing actions under the Clayton Act are not usually afforded the benefit of discovery. ${ }^{83}$ If the Bankers Trust court's argument were correct, then it would follow that the discovery rule should apply to the Clayton Act as well as to most other statutory as well as common law actions. The court ignores the fact that other characteristics of the statute-that many of the predicate acts establishing a RICO violation involve fraud-require the incorporation of discovery principles into a RICO accrual rule. ${ }^{84}$

Moreover, the two courts adopting the separate accrual discovery rule seem to have overlooked the implications of this rule for plaintiff's remedy. Under the separate accrual discovery rule, plaintiff may only recover damages for those acts that took place within the four years before he filed his claim. This corollary for damages effectively diminishes any advantages derived from allowing the plaintiff time to discover his injury: The damages corollary put forth in the concurrence subtracts the time allowed to discover the action from the four year statute of limitations. ${ }^{85}$

denied, 479 U.S. 1054 (1987). Both cases apply the continuing violation rule to a conspiracy. By disavowing Compton, the Ammann court fails to acknowledge that part of its rule comes from Compton. Similarly, by omitting the flaws of the discovery rule, the opinion fails to show why this new hybrid rule should be adopted.

79. 859 F.2d 1096 (2d Cir. 1988), cert. denied sub nom. Soifer v. Bankers Trust Co., 109 S. Ct. 1642 (1989).

80. Id. at 1102 .

81. Id.

82. 15 U.S.C. $\$ 15$ (a) (1988).

83. See supra note 51 .

84. See supra notes 53-55.

85. If the last act occurred in 1982, and the injury not discovered until 1984, plaintiff does not have four years from the discovery of the injury in which to file a claim; if he waits until 1988, he will be barred, as no injuries occurred after 1982 . If he is to recover damages, he has only two years from the time of discovery of the injury in which to bring his claim. 
The effective curtailment of the four year statute of limitations that results from the separate accrual discovery rule is indeed a serious flaw. Because the Supreme Court has ruled that a four year limitations period provides the best balance of plaintiffs' and defendants' rights, ${ }^{86}$ and because most courts would support allowing the plaintiff time to discover his cause of action in addition to the limitations period, ${ }^{87}$ this flaw in the separate accrual discovery rule seems fatal.

\section{The Last Predicate Act Rule}

Several district courts have eschewed altogether the application to RICO of the general Federal rule, the discovery rule, opting instead for an alternate rule borrowed from the more specific context of a continuing violation under antitrust law. ${ }^{88}$ Under the last predicate act rule, plaintiff's claim accrues upon commission of the last act in the pattern of acts required by RICO. Thus, in County of Cook v. Berger, ${ }^{89}$ plaintiff, who alleged a conspiracy among several local officials to commit a series of harms against him, was held not to be time barred because the most recent injury occurred within the applicable limitations period preceding the filing of the claim. ${ }^{80}$

The last predicate act rule, however, explicitly differs from the antitrust-based rule of continuing violations in the scope of the injuries for which the plaintiff may recover. Under the Berger rule, the plaintiff may recover damages for the entire pattern of RICO violations, even though some acts may have occurred outside the limitations period-more than four years earlier.$^{91}$ In contrast, the rule as applied in antitrust law limits

86. S S ${ }^{\prime}$ Agency Holding Corp. v. Malley-Duff \& Assocs., 483 U.S. 143, 155-56 (1987) (five year catch-all limitation for criminal actions "does not reflect any congressional balancing of the competing equities unique to civil RICO actions").

87. Sie supra note 65.

88. Sk supra note 44. To take advantage of the continuing violation rule of accrual under antitrust law, the antitrust plaintiff must show that an "overt act" was committed by the wrongdoer pursuant to a contract, a combination, or a conspiracy within the limitations period. KFC Corp. v. Marion-Kay Co., 620 F. Supp. 1160, 1167 (S.D. Ind. 1985); see also Pace Indus. v. Three Phoenix Co., 813 F.2d 234, 239 (9th Cir. 1987) (enforcement of illegal contract is overt act).

The concept of "overt act" derives from conspiracy law. It is based on the theory that a civil conspiracy is only actionable where it results in an injury to the plaintiff; an overt act cannot be established by evidence of a conspiracy alone, without any evidence of acts performed pursuant to that conspiracy. Rose Hall, Ltd. v. Chase Manhattan Overseas Banking Corp., 494 F. Supp. 1139, 1160 (D. Del. 1980) (opinion following reargument). In RICO, an overt act is defined as a predicate act under 18 U.S.C. \$1961(1) (1982) (defining "racketeering activity"). See Lewis ex rel. Nat'l Semiconductor Corp. v. Sporck, 612 F. Supp. 1316, 1325 (N.D. Cal. 1985).

89. 648 F. Supp. 433, 435 (N.D. Ill. 1986).

90. Berger was decided before the Agency Holding decision in which the Supreme Court held that courts should borrow the Clayton Act's four year limitations period and apply it to RICO. The Berger court used a state limitations period. As the plaintiff did not allege any lag time between the occurrence of the acts and the discovery of the injuries, the Berger court did not have occasion to consider whether the last predicate act rule should allow time for the discovery of the injury. Presumably, the rule, if true to its antitrust roots, would not allow for discovery. See supra note 51 and accompanying text.

91. Berger, 648 F. Supp. at 434-35. 
damages to those acts that occurred within the four years before the filing of the claim. ${ }^{22}$

The Berger court expressly viewed the pattern requirement of RICO as the element that should above all determine the accrual of a RICO cause of action. ${ }^{93}$ The court cited United States $v$. Field, ${ }^{94}$ a criminal RICO case, as precedent for applying the continuing violation rule to RICO. The Field court similarly stressed the pattern requirement as the reason for borrowing the continuing violation rule from antitrust law. Berger thus held that the continuing violation rule should apply to RICO because "the language of [RICO], which makes a pattern of conduct the essence of the crime, "clearly contemplates a prolonged course of conduct." "9s The opinion, however, fails to reconcile a rule of accrual that starts the statute of limitations running at the last act in the pattern with the policies underlying the RICO statute and the policy of the general Federal rule of accrual, which allows for discovery of the injury. ${ }^{96}$ As demonstrated in Part I, discovery principles should play an integral role in determining the appropriate RICO accrual rule.

In conclusion, the chief fault of the last predicate act rule lies in its arbitrariness. The plaintiff's recovery depends entirely on whether he discovers the action in time. If he does happen to discover the requisite pattern of injuries, he stands to gain a windfall of treble damages if the pattern of injuries stretches back over time; an equally deserving plaintiff who remains ignorant goes uncompensated.

92. See Zenith Radio Corp. v. Hazeltine Research, Inc., 401 U.S. 321, 338, reh'g denied, 401 U.S. 1015 (1971) (in conspiracy to violate antitrust laws, new cause of action accrues with each injurious act; as to damages, statute of limitations runs from commission of act, but future damages will be allowed in some cases). In some antitrust cases, plaintiff can recover for acts taking place outside the limitations period if damages from such acts became ascertainable only during the four years preceding the filing of the claim. Program Eng'g, Inc. v. Triangle Publications, Inc., 634 F.2d 1188,1193 (9th Cir. 1980).

93. In its analysis, the Berger court stressed the pre-eminence of the pattern requirement in the RICO action: "Civil RICO was designed to protect those who have been harmed by a pattern of illegal conduct. The Supreme Court has emphasized the need for continuity plus relationship in determining the existence of a pattern of racketeering activity." Berger, 648 F. Supp. at 435 (citing Sedima, S.P.R.L. v. Imrex Co., 473 U.S. 479 (1985)) (emphasis added).

94. 432 F. Supp. 55 (S.D.N.Y. 1977), affd mem., 578 F.2d 1371 (2d Gir.), cert. dismissed, 439 U.S. 801 (1978).

95. Berger, 648 F. Supp. at 434 (quoting Field, 432 F. Supp. at 59) (citation omitted) (emphasis added).

96. A commentator similarly believes that it is not necessary to incorporate discovery principles into an accrual rule for RICO. See Comment, supra note 28, at 1426, 1433 (stating rule "workable in all the circuits" and "most appropriate given the unique character of civil RICO"). The Comment rests its conclusion on the assumption that the imbalance of equities in favor of the plaintiff will, in most circuits, be limited by a very strict definition of pattern. Id. at 1426-27. In light of the Supreme Court's recent decision interpreting the pattern requirement of RICO, and in particular holding that a single scheme involving many acts could constitute a pattern, this premise is no longer valid. See H.J., Inc. v. Northwestern Bell Tel. Co., 109 S. Ct. 2893 (1989). 


\section{The Last Predicate Act Discovery Rule}

The most recently introduced accrual rule, the last predicate act discovery rule, combines the advantages of the discovery-based rules with the pattern-based last predicate act rule. Under the last predicate act discovery rule, the statute of limitations does not begin to run until the plaintiff discovers the last predicate act of the defendant. ${ }^{97}$ To look at it from the point of view of a court presented with a claim, an action is timely if the plaintiff can allege that he discovered an act committed by the defendant that is violative of RICO within the four years preceding the filing of the claim.

Under this rule, unlike the separate accrual discovery rule, the last predicate act need not have caused injury to the plaintiff. Thus, in Keystone Insurance Co. v. Houghton ${ }^{88}$ the Third Circuit, reversing the district court, held that plaintiff, an insurance company that was one of several companies injured by defendant's pattern of defrauding insurers, was not time barred if it could allege that it discovered that defendants had committed a predicate act against one of the other companies within the past four years.

In adopting the last predicate act discovery rule, the Keystone Insurance court implicitly recognized the difficulty of characterizing RICO in any one way. In contrast, when adopting the last predicate act rule, the Berger court failed to recognize that many RICO claims can be characterized as fraud claims and that Federal common law requires the application of discovery principles to such claims. The Ammann court, while recognizing the importance of discovery principles, devised a rule that only applied discovery principles to the discovery of the injury and not to the discovery of the pattern..$^{99}$

While the Keystone Insurance court's rule is optimal according to the principles established above ${ }^{100}$ in its characterization of the RICO claim, the court fails to consider fully any other Federal policies before arriving at the rule. As demonstrated above, ${ }^{101}$ the Federal policy that accrual and limitations rules should reflect balancing of plaintiffs' and defendants' rights merits consideration. The last predicate act discovery rule, by al-

97. See Keystone Ins. Co. v. Houghton, 863 F.2d 1125, 1130 (3d Cir. 1988). The Keystone Ins. caurt does not hold that the last predicate act discovery rule should be the sole accrual rule for RICO. Ih. at 1130-31 (implying that discovery rule should apply in those cases where the injury to the plaintiff is singlefold). For taxonomy's sake, this Note will treat the Keystone Ins. case as standing for the proposition that the last predicate act discovery rule is the best rule of accrual for RICO.

98. Id. at 1130 .

99. This view is in contrast to that espoused by the Keystone Ins. court. "RICO is a crime of association, which is violated, inter alia, by 'any person . . . associated with any enterprise . . . the activities of which affect . . . commerce, conduct|ing] . . [ [the] enterprise's affairs through a pattern of racketeering.' Therefore the discovery rule must apply to the pattern element as well as the injury element." Keystone Ins., 863 F.2d at 1130 (quoting 18 U.S.C. \$ 1962(c) (1988)).

100. Sep supra Part I.

101. Id. 
lowing plaintiff to recover for all acts committed by the defendant that caused injury to the plaintiff, and not just those acts that occurred within the four years prior to the filing of the claim, may tip the balance of equities in favor of the plaintiff and should not be adopted without explicit consideration. Attempting to justify its adoption of the last predicate act discovery rule, the court argued that allowing recovery for some acts and not others based solely on the line drawn by the limitations period would prove arbitrary. ${ }^{102} \mathrm{~A}$ better argument would have alluded to the inherent temporal limitation imposed by the definition of pattern. ${ }^{103}$

\section{The Clayton Act Rule}

A fifth accrual standard, adopted by the district court in Armbrister $v$. Roland International Corp. ${ }^{104}$ results from the analogy of civil RICO to the Clayton Act-developed in the Agency Holding case-as the sole factor for determining RICO accrual. ${ }^{105}$ With this analogy in mind, the court chose the antitrust accrual rule that best fit the facts of the case. ${ }^{108}$

Armbrister involved a scheme among defendants to commit fraud in the sale of land. Although the sales took place ten years before the filing of the suit, plaintiffs were still making payments on the sales contract. ${ }^{107}$ The court held that plaintiffs were time barred, analogizing their claim to a body of injury-on-the-contract antitrust cases. When a plaintiff's antitrust injury stems from the carrying out of a contract, plaintiff's cause of

102. Keystone Ins., 863 F.2d at 1131 (Given "the federal interest in providing relief to those who are injured by a continuous and related course of conduct, it would be incongruous to bar, on statute of limitations grounds, recovery for predicate acts taking place outside the limitations period." (quoting County of Cook v. Berger, 648 F. Supp. 433, 435 (N.D. Ill. 1986))).

103. See supra text accompanying note 59. The justification of this rule lies in the fact that under the ten year definition of pattern, plaintiff could only recover for those acts occurring within ten years of the occurrence of the most recent act.

104. 667 F. Supp. 802 (M.D. Fla. 1987). For another case discussing but not adopting this rule, see 5 Penn \& Co. v. Shearson Lehman Bros., No. 87-1357, slip. op. (E.D. Pa. Nov. 3, 1987), (WESTLAW DCT database) (dicta, as plaintiff's claim time barred under any theory of accrual considered by court).

105. Comment, supra note 28 , at 1418 .

106. The method of accrual adopted by the Armbrister court, termed the Clayton Act rule by this Note, should be distinguished from the last predicate act rule, also an accrual method derived from the Clayton Act. "This Court believes that the rationale of the Agency Holding decision requires an application of the limitations accrual principles of the Clayton Act . . . " Gilbert Family Partnership v. Nido Corp., 679 F. Supp. 679, 686 (E.D. Mich. 1988) (applying last predicate act rule to civil RICO accrual).

For the sake of convenience, the term "Clayton Act rule" is shorthand for the injury-on-thecontract rule described herein. This terminology does not imply that the last predicate act rule is not also derived from antitrust law. In a contract-based injury, rights are fixed at the time of signing, and therefore the injury resulting from that particular distribution of rights is ascertainable and ripe. Where injury is caused by some other type of relationship, such as the relationship between two competitors, the injury resulting from each anticompetitive act is distinct. The latter situation is truly an ongoing or continuous violation, whereas the contract-based injury is not. Thus, in the second situation the continuing violation rule of accrual would apply, the cause of action would accrue from the occurrence of the last predicate act in the series, and plaintiff could recover for injury suffered from all such acts within the limitations period.

107. Armbrister, 667 F. Supp. at 806. 
action generally accrues from the contract's date of execution. ${ }^{108}$ The Armbrister court, applying the rule of accrual specific to Clayton Act contract cases, held that plaintiff's cause of action accrued upon the signing of the contract, well outside the four year limitations period for RICO. ${ }^{109}$

The Clayton Act rule in Armbrister may be limited to its facts. No other court has adopted this rule, perhaps because the discovery rule works just as well, if not better, in the situation in which a plaintiff suffers a single fraud injury. ${ }^{110}$ Moreover, the court derived its rule not from a general consideration of RICO and other Federal policies, but from the particular facts of the transaction. Presumably, the same court would have applied another rule of accrual for a non-contract injury. ${ }^{111}$

\section{B. The Optimal Rule for Accrual of a RICO Action}

The discussion of the various rules has shown that two competing characterizations of RICO exist. The first characterization views RICO as an action to recover damages for several individual injuries. As many of these individual injuries are fraud, the discovery rule should determine accrual. The second view holds that RICO is primarily an action to recover for a continuing violation.

RICO's pattern requirement is the foundation of this second understanding of RICO. This view can be justified on at least two other grounds. First, Congress intended the RICO cause of action to combat what it perceived to be an increasingly serious phenomenon: the infiltration of legitimate businesses by organized crime with money gleaned from those associations' ill-gotten gains. ${ }^{112}$ The pattern requirement was therefore intended to exclude from the RICO cause of action those plaintiffs experiencing isolated threats. Second, the Supreme Court has focused on the pattern requirement as a means of interpreting the statute and has concluded that implicit in the definition of pattern is continuity or the threat of continuity. ${ }^{113}$ An accrual rule must allow plaintiff a chance to demonstrate continuity.

At the same time, characterizing the claim primarily as an action to recover for a continuing violation shifts the focus of the RICO action away from the nature of the specific racketeering acts, many of which involve fraud. Federal jurisprudence requires application of the discovery

108. Kaiser Aluminum \& Chem. Sales, Inc. v. Avondale Shipyards, Inc., 677 F.2d 1045 (5th Cir. 1982), curt. denied, 459 U.S. 1105 (1983); Aurora Enters., Inc. v. Nat'l Broadcasting Co., 688 F.2d 689 (9th Cir. 1982).

109. Armbrister, 667 F. Supp. at 809.

110. See supra text accompanying note 69.

111. For further discussion of the Clayton Act rule, see Comment, supra note 28, at 1411 , 1418-20, 1431, 1432-33 (predicting Clayton Act rule to receive wide recognition after Agency Holding).

112. Ser Bradley, supra note 47.

113. H.J., Inc. v. Northwestern Bell Tel. Co., 109 S. Ct. 2893 (1989). 
rule in such actions. ${ }^{\mathbf{1 1 4}}$ Given the principles for determining accrual rules developed in Part I requiring (1) characterization and (2) weighing any other Federal jurisprudential or policy principles, the last predicate act discovery rule adopted by the Third Circuit seems the most sensible rule for RICO accrual, although the court does not itself weigh these general Federal principles in its decision. By running the statute of limitations from the discovery of the last predicate act of the defendant, and by allowing recovery for the entire pattern of injurious acts, the last predicate act discovery rule recognizes the competing characterizations of RICO as an action to recover for a continuing violation and as an action to recover for injury caused by fraud. This method of accrual also maintains a balance of plaintiffs' and defendants' rights, as it limits recovery to those acts falling within the meaning of "pattern," which by definition cannot occur more than ten years before the last predicate act.

\section{CoNCLUSION}

Because it accounts for the two competing characterizations of RICO while maintaining a balance between plaintiffs' and defendants' rights, the last predicate act discovery rule provides the best solution to the complex problem of determining when a RICO cause of action accrues. Moreover, courts, even those that have previously used other accrual methods in RICO actions, may freely adopt a new rule.

Accrual of an action based on a Federal statute is a flexible concept. As this discussion has shown, distinctions among the various rules become blurred as courts try to cope with various factual situations that arise under new statutes. For example, the discovery rule was originally applied narrowly. ${ }^{115}$ Now the discovery rule governs most Federally created causes of action, regardless of whether these actions involve fraud. ${ }^{116}$ Antitrust actions originally accrued with the occurrence of the injurious act. ${ }^{117}$ Now the rules of antitrust accrual allow the separate accrual of causes of action, in the case of a continuing violation, and apply a form of the discovery rule, in the tolling doctrine of fraudulent concealment.

Resolving uniformly when a RICO action accrues offers both parties and courts some needed certainty, and provides courts with an opportunity to limit the RICO action without an explicit rewriting of the statute's terms. Of the several rules developed here, the last predicate act discovery rule nicely balances the policy justifications for the RICO statute with the Federal equitable interests in allowing plaintiffs time to discover their injuries, and in an even distribution of plaintiffs' and defendants' rights.

114. See supra text accompanying notes 52-55.

115. See supra note 53 .

116. See supra note 65 .

117. See 54 C.J.S., supra note $44, \S 203$. 